\title{
Trichothecene (Trichodermin) Production in Trichoderma
}

\author{
Manika Sharma ${ }^{1 *}$, Pratibha Sharma ${ }^{2}$, M. Raja ${ }^{2}$, Krishan Kumar ${ }^{1}$, \\ Subhash Chandra ${ }^{1}$ and Richa Sharma ${ }^{1}$
}

\author{
${ }^{1}$ Department of Food \& Biotechnology, Jayoti Vidyapeeth Women's University, \\ Jaipur, Rajasthan, India \\ ${ }^{2}$ Division of Plant Pathology, Indian Agricultural Research Institute, New Delhi, India \\ *Corresponding author
}

\begin{tabular}{|c|c|}
\hline & A B S T R A C T \\
\hline Key & \multirow{4}{*}{$\begin{array}{l}\text { Fungi form an important group of microorganisms comprising of both forms } \\
\text { Filamentous and Non-filamentous but mycotoxin production is mostly seen } \\
\text { associated with terrestrial filamentous fungi like molds. Symbiosis between } \\
\text { plants and endophytes is well known in which symbionts provide shelter to latter } \\
\text { and fungi produces some bioactive compounds which play important role in } \\
\text { mitigating the effect of pathogens, insectides etc and defend the plant from attack. } \\
\text { Toxigenic fungi can produce mycotoxin like Trichothecenes, aflatoxins, } \\
\text { rubratoxins, ochratoxins, fumonisins etc. Among them trichothecenes play } \\
\text { important role to be used as potential biopesticides. Potentially hazardous } \\
\text { concentrations of the trichothecene mycotoxins can occur naturally in cereals and } \\
\text { grains. }\end{array}$} \\
\hline $\begin{array}{l}\text { Trichothecene, } \\
\text { Mycotoxins, } \\
\text { HA:Harziandione, } \\
\text { Trichoderma. }\end{array}$ & \\
\hline Art & \\
\hline $\begin{array}{l}\text { Accepted: } \\
\text { 12 June } 2016 \\
\text { Available Onli } \\
\text { 10 July } 2016\end{array}$ & \\
\hline
\end{tabular}

\section{Introduction}

The species of Trichoderma are well known for their biocontrol activity against many plant pathogens that cause major problems in the current agricultural scenario (Sharma et al., 2011). The major biocontrol process involves antibiosis, providing plant nutrition and mycoparasitism (Janisiewicz and Korsten, 2002). Trichoderma species are biofertilizers, that induces plant defense responses, and to enhanced tolerance to abiotic stresses (Shoresh et al., 2010; Hermosa et al., 2012). There are different species of Trichoderma producing bioactive compouns which act as mycotoxins One of them is Trichothecene. It is a sesquiterpenoid derived secondary metabolites synthesized mainly by Fusarium other fungal genera like Trichoderma, Trichothecium, Stachybotrys (Shentu et al., 2014; Wilkins et al., 2003). It is known that these sesquiterpenoid compounds are also produced by Trichoderma arundinaceum and $T$. brevicompactum which are found harmful to plants and to the animals feeding on infected fodder. Harziandione and trichodermin have been most widely studied antifungal compounds known from long time (Rocha et al., 2005; Jin et al., 2007; 
Degenkolb et al., 2008; Cardoza et al., 2011; Cole et al., 2003), and their biosynthetic pathways have been completely known by now.

Mycotoxins are found to accumulate in plants, and can also lead to the development of (mycotoxicoses) in humans and animals (Janisiewicz et al., 2002).

The chemical structure of Trichothecens comprise of a trichothecene ring, which contains an olefinic ring at C-9,10; and an epoxide group of $\mathrm{C}-12,12$. Trichotheceneare mainly produced by Fusarium, Myrothecium, Spicellum, Stachybotrys, Cephalosporium, Trichoderma, and Trichothecium (Shentu et al., 2014). These fungi, of the order Hypocreales, are known throughout for there adaptability and colonizing behavior and growth on substrates with a wide range of moisture availability and nutrient content. The genus Fusarium, there are species whizh invade important plant pathogens and causes blights,wilts, and ear rots in grains, like wheat, barley, oats and maize (Hermosa et al., 2012). The mechanism of action of mycotoxin mainly comprised of toxicity studies showed that trichothecenes inhibit protein synthesis, by preventing peptide bond formation at the peptidyl transferase center of the $60 \mathrm{~S}$ ribosomal subunit. The polypeptide chain termination may also be inhibited (Jin et al., 2007; Degenkolb et al., 2008). Trichothecenes were also shown to inhibit protein synthesis in mitochondria (Cole et al., 2003) and interaction with protein sulfhydryl groups. The activity of trichothecenes then produces harmful levels of oxidative stress due to generation of free radicals.

\section{Physical and Chemical properties}

The trichothecenes are a family of closely related chemical compounds called sesquiterpenoids. There are 200 Trichothecene known. The trichothecene mycotoxins are nonvolatile and have lowmolecular-weight (MW 250-550) compounds. Sesquiterpenoids are relatively insoluble in water but highly soluble in acetone, ethyl acetate, chloroform, dimethyl sulfoxide (DMSO), ethanol, methanol, and propylene glycol. The most important mycotoxin is T-2 toxin known for its availability and relatively high toxicity. Extraction of trichothecene from fungas yield yellow brown liquid which on evaporation form a cyrtalline product.Purified trichothecene generally have low vapour pressure, but they do vapourize when heated in organic solvents.

\section{Trichothecene from Trichoderma}

Trichodermin is known to have stronger antifungal activity against Saccharomyces cerevisiae, Kluyveromyces marxianus, Candida albicans, $C$. glabrata, $C$. tropicalis, and Aspergillus fumigatus as compared to antibiotics. To date, more than 200 trichothecenes have been reported and are divided into four types (A-D) according to their chemical structures (Sharma et al., 2011). Furthermore, trichodermin had been established a reputation of been a potential role in biological control activity on various soil borne and seed borrne phytopathogenic fungi such as Botrytis cinerea and Rhizoctonia solani. Yeild of the Trichodermin can be improved from low fermentation units $325 \mu \mathrm{g} / \mathrm{L}$ to high (Jin et al., 2007). In order to enable large-scale production, it is very important to look for the factors affecting the yield and optimization parameters in the fermentation conditions in industry. However, the improvement on trichodermin yield in Trichoderma using precursor/elicitor has not been reported. There are various gene expression studies conducted by different 
research groups to understand the biosynthetic pathway of trichothecene in a better way.

The trichothecene biosynthetic gene cluster comprises of set of seven major genes (tri3, tri4, tri6, tri10, tri11, tri12 and tri14) found. In Fusarium tri4, tri11 are directly involved in trichothecenes biosynthesis (Cardoza et al., 2011). The tri5 gene (encoding the trichodiene synthase), is located outside the gene cluster and is known to be responsible for the first committed step in HA biosynthesis (Cardoza et al., 2011). The influence on the trichodermin production as well as the expression levels of three genes, Tbtri4,Tbtri5 and Tbtri11 which are directly involved in trichothecene biosynthesis were investigated.

In recent years, the world is experiencing an increase in awareness of mycotoxin contamination of building materials, grains and air-handling systems. These problems are caused by trichothecenes, which range from relatively simple structures to those with more complex, macrocyclic structures. Based on genetic sequence data the phylogenetic analyses lead to a better understanding of the evolution of trichothecene-producing fungi. Phylogenetic work on the trichothecene gene cluster indicates that, there has been consolidation of TRI genes into fewer loci in some fusaria .Newer Researches will contribute the evolution affects of mycotoxin-producing genes. Studying fungal populations and various genetic linkages will also bring a better understanding of how pathogenic fungi spread throughout the world. Comparison of gene sequences from expanding databases may also contribute to identification of trichothecene-related genes that may lead to new control strategies to reduce both crop diseases caused by the fungi and the mycotoxin contamination problems associated with these diseases. Combination of chemical and genetic analysis of trichothecene biosynthesis provide us better understanding of evolutionary mechanisms involved in Trichothecenes.

\section{Acknowledgments}

The study was supported by ICAR (Indian Council for Agriculture Research) funded (NAE) Niche area of Excellence'sExploration and Exploitation of Trichoderma as antagonist soil borne pathogens"' and Jayoti Vidyapeeth Womens University, Jaipur for guidance.

\section{References}

Bertagnolli, B. L., Daly, S. and Sinclair J. B. 1998. "Antimycotic compounds from the plant pathogen Rhizoctonia solani and its antagonist Trichoderma harzianum," Journal of Phytopathology., 146: 131-135.

Cardoza, R.E., M.G. Malmierca, M.R. Hermosa, N.J.Alexander and S.P. McCormic. 2011.

Cardoza, R.E., Malmierca, M.G., Hermosa, M.R., Alexander, N.J., McCormick, S.P., Proctor, R.H., Tijerino, A.M., Rumbero, A., Monte E, Gutiérrez S. 2011. Identification of loci and functional characterization of trichothecene biosynthetic genes in the filamentous fungus Trichoderma. Appl Environ Microbiol., 77:4867-4877.

Carrasco, L., Barbacid, M., Vazquez, D. 1973. The trichodermin group of antibiotics, inhibitors of peptide bond formation by eukaryotic ribosomes. Biochim. Biophys. Acta 312: 368-376.

Cole, R.A., Jarvis, B.B., Schweikert, M.A.2003. Handbook of Secondary Metabolites; Academic Press:New York, NY, USA, pp. 199-560. 
Corley, D.G., Miller-Wideman, M., Durley, R.C. 1994. Isolation and structure of harzianum A: a new trichothecene from Trichoderma harzianum. J Nat Prod., 57:422-425.

Cundliffe, E., Cannon, M.,Davies, J. 1974. Mechanism of inhibition of eukaryotic protein synthesis by trichothecene fungal toxins. Proc. Natl. Acad. Sci. USA 71: 30-34.

Cundliffe, E., Davies, J.E.1977. Inhibition of initiation, elongation, and termination of eukaryotic

Degenkolb, T., Dieckmann, R., Nielsen, K.F., Gräfenhan, T., Theis, C., Zafari, D., Chaverri, P., Isamaiel, A., Brückner, H., von Döhren, H., Thrane, U., Petrine, O., Samuels, G.J. 2008. The Trichoderma brevicompactum clade: a separate lineage with new species, new peptabiotics, and mycotoxins. Mycol Prog., 7:177-219.

Desjardins, A.E. $2006 . \quad$ Fusarium Mycotoxins Chemistry, Genetics and Biology; APS Press: Eagan, MN,USA, pp. 1-260.

Godtfredsen, W.O., Vangedal S. 1965. Trichodermin, a new sesquiterpene antibiotic. ActaChem Scand., 19:1088-1102.

Groove, J.F.2007. 'The Trichothecenes and their biosynthesis." Fortschritte der Chemie organischer Naturstoffe, 88: 63-130.

Hermosa, R., Viterbo, A., Chet, I., Monte, E., 2012. Plant-beneficial effects of Trichoderma and of its genes. Microbiology., 158:17-25.

Identification of loci and functional characterization of trichothecene biosynthesis genes in filamentous fungi of the genus Trichoderma. Applied Environ. Microbiol., 77: 4867-4877.

Janisiewicz, W., Korsten, L .2002. Biological control of postharvest diseases of fruits. Аnnu. Rev. Phytopathol. 40: 411-441.

Jin, H.Z., Lee, J.H., Zhang, W.D., Lee, H.B., Hong, Y.S., Kim, Y.H., Lee, J.J. 2007.Harzianums A and B produced by a fungal strain, Hypocrea $\mathrm{sp}$ F000527, and their cytotoxicity against tumor cell lines. J Asian Nat Prod Res., 9:203-207.

Kimura, M., Tokai, T., Takahashi-Ando, N., Ohsato, S., and Fujimura, M. 2007. "Molecular and genetic studies of Fusarium trichothecene biosynthesis: pathways, genes, and evolution. Bioscience, Biotechnology and Biochem., 71 (9): 2105- 2123.

McLaughlin, J.E., Bin-Umer, M.A., Tortora, A., Mendeze, N., McCormick, S., Tumer, N.E.2009. A genome-wide screen in Saccharomyces cerevisiae reveals a critical role for the mitochondria inthe toxicity of a trichothecene mycotoxin. Proc. Natl. Acad. Sci. USA .106: 21883-21888.

McMullen, M., Jones, R., Gallenberg, D. 1997. Scab of wheat and barley: A reemerging disease of devastating impact. Plant Dis. 81: 1340-1348.

Nielsen, K.F., Gräfenhan, T., Zafari, D., Thrane, U. 2005. Trichothecene production by Trichoderma brevicompactum. J Agric Food Chem., 53: 8190-8196.

PloS one. DOI: 10.1371/ journal.pone.0094203.

protein synthesis by trichothecene fungal toxins. Antimicrob. Agents Chemother. 11:491-499.

Riley, R.T., Norred, W.P.1996. Mechanisms of Mycotoxicity. In The Mycota VI: Human and Animal Relationships; Howard, D.H., Miller, J.D., Eds.; Springer-Verlag: New York, NY, USA, pp. 193-211.

Rocha, O., Ansari, K., Doohan F.M., 2005. 
Effects of trichothecene mycotoxins on eukaryotic cells: a review. Food Addit Contam., 22:369-378.

Sharma, P., Vignesh, K.P., Ramesh, R., Saravanan, K., Deep, S., Sharma, M., Mahesh, S., Dinesh, S. 2011. Biocontrol genes from Trichoderma species- A Review. Afr. J. Biotechnol., 10(86): 19898-19907.

Shentu. X.P., W.P. Liu, X.H. Zhan, Y.P. Xu and J.F. $\mathrm{Xu}$.2014. Transcriptome sequencing and gene expression analysis of Trichoderma brevicompactum under different culture conditions.

Shoresh, M., Harman G.E., Mastouri, F. 2010. Induced systemic resistance and plant responses to fungal biocontrol agents. Annu Rev Phytopathol., 48:2143.

Suneja, S.K., Wagle, D.S., Ram, G.C.1989. Effect of oral administration of T-2 toxin on glutathione shuttle enzymes, microsomal reductases and lipid peroxidation in rat liver. Toxicon 27: 995-1001.

Ueno, Y .1994. "Toxicological features of T-2 toxin and related trichothecenes," Fundamental and Applied Toxicology.,
4(2): S124-S132.

Ueno, Y. 1977. Mode of action of trichothecenes. Pure Appl. Chem., 49: 1737-1745.

Ueno, Y. The toxicology of mycotoxins. Crit. Rev. Toxicol. 1985. Pace, J.G.; Watts, M.R.; Canterbury, W.J. T-2 mycotoxin inhibits mitochondrial protein synthesis. Toxicon ., 26: 7785.

Ueno, Y., Matsumoto, H.1975. Inactivation of some thiol-enzymes by trichothecene mycotoxins from Fusarium species. Chem. Pharm. Bull. 23: 2439-2442.

Ueno, Y.1985. "The toxicology of mycotoxins," Critical Reviews in Toxicology., 14: 99-132.

Wilkins, K., Nielsen, K.F., and Din, S.U. 2003. Patterns of volatile metabolites and nonvolatile trichothecenes produced by isolates of Stachybotrys, Fusarium, Trichoderma, Trichothecium and Memnoniella. Environ. Sci. Pollut. Res., 10: 162166.

\section{How to cite this article:}

Manika Sharma, Pratibha Sharma, M. Raja, Krishan Kumar, Subhash Chandra and Richa Sharma. 2016. Trichothecene (Trichodermin) Production in Trichoderma. Int.J.Curr.Microbiol.App.Sci. 5(7): 382-386. doi: http://dx.doi.org/10.20546/ijcmas.2016.507.041 